\title{
The Impact of Working Capital Management on Firm Performance: An Empirical Evidence from the BIST SME Industrial Index
}

\author{
Fatih Konak and Ela Nur Güner
}

\begin{abstract}
Nowadays, it is crucial to be aware of the impacts of management of working capital indicators on firm performance. In order to figure out the existence of this relationship, there have been many research conducted. In this context, the main aim of this research is to determine the relationship between working capital management and firm performance of twenty-nine of thirty three companies listed on the Borsa Istanbul SME Industrial Index from 2011 to 2014. In this respect, pooled OLS test and cross sectional time series analysis technique is employed. We found negative relationship between Net Margin and, Short Term Debt Turnover Days and Cash Conversion Cycle. It can be interpreted that effective management of working capital, such as decrease in Short Term Debt Turnover Days, can positively affect firms' performance.
\end{abstract}

Index Terms-Borsa Istanbul SME industrial index, working capital management, firm performance.

\section{INTRODUCTION}

As a result of that the dimensions of enterprises change from local to national and from national to international along with the competition exhibited in marketing environment in the globalizing world, the management method and efficiency of working capital,which are important significiantly for companies to continue their life, has been more and more important.Through management of working capital, some issues, such as, how much investment will be made for which entity, and through which resources these investments will be financed, are intented to be determined. In this context, it has been investigated and discussed for years that whether significant relationship between management of working capital and firm performance have existed. It is predictable that the companies aiming at expanding constantly and obtaining maximum profitability can accomplish their goals with a strong financing and quality management.

Acceptance of effective and efficient management understanding in terms of management of working capital will no doubt provide a positive contribution to the performance of company. An effective management of working capital will benefit not only to enterprise but also country's economy.

In this context, SMEs,considered as backbone of the the dynamic and immersive elements of economy are very

Manuscript received July 19, 2015; revised April 14, 2016

The authors are with Hitit University/ FEAS/ Department of Business Administration, Çorum, Turkey (e-mail: fatihkonak@hitit.edu.tr, ela.gnr.05@hotmail.com ). important since they contribute to development of country through their flexible structures and harmonizing to changing conditions [1]. This importance has been perceived even better in the developed or developing countries especially in the countries like Turkey, faced with economic crisis from time to time.

Ref. [2] claimed that an effective working capital would make increase the value of the company. Similarly, [3] pointed out in their study that a strong relationship existed between management of working capital and performance of company. In respect of SMEs, [4] emphasized in his recent study the importance of management of working capital in terms of financial performance in SMEs to be increased. On the other hand, [5] determined that SMEs often used equity, their capacity utilization rates were low, and they couldn't provide sufficient employment.

Taking into account the importance of management of working capital and concept of working capital for SMEs, the main purpose of our study is measurement and revelation of the possible relationship between company's performance and management of working capital in terms of the EIST-SME industry index quoted companies.

\section{WorkING CAPITAL MANAGEMENT}

In the most common sense, working capital can be expressed as sum of owned assets and current assets. In other words, working capital is used to afford short-term expenses, such as,raw materials, labor, general administrative expenses, tax, maintenance and repair expenses, energy and insurance expenses emerged during the period starting from the establishment of a business to the extend of going into operation and maintaining its activities [6]. Working capital, also known as business capital, exhibits great importance in order to afford company to work with full capacity, continue production uninterruptedly, decrease the risk of liquidity,and not being in difficult situations financially in crisis situations [7]. We witness management of working capital at least once within the one accounting period of enterprise as the efficiently and effectively administration of the assets that are convertable to cash. These current assets consist of money, securities, stocks, receivables and other current assets. In terms of management of working capital, dormant business capital leads to reduction of profitability and accordingly working capital deficit leads to the risk of unpaid debts [8]. Failing to manage the working capital effectively leads to some negative consequences, These are as follows [7]:

- The current assets of every company has a cost. In case 
the current assets are very much, and company finance these assets with foreign resources, financing costs of company will be increased. If company finances these costs using its equities, then it will not be able to benefit alternative use of equity. In other words, regardless of a company's financing way; either using foreign resources or equities; having excessive working capital will result in a negative impact on profitability of company.

- Another negative result is the lack of sufficient level of working capital. A company aims to use its capacity fully to profit and provide its continuity, so it needs sufficient working capital. Usage of full capacity requires continuity of production at a company to be ensured. As a result of failing to provide continuity of production; some problems, such as, customer losses, cost increase,failing to timely delivery of orders will occur.

- If companies don't take necessary precautions in terms of lack of working capital and to compensate their faults in the management of working capital, they can even take decision of clarification of company.

- Banks, credit sales vendors, stock or bond investors need to have necessary working capital to avoid losing their status in the market and reducing their credit rating. Otherwise, they can fail coping with these problems in future, and they may have to face big losses.

In respect to fixes assets, working capital is short-term and its liquidity is higher and can be divided, working capital decisions is renewable in short time, and working capital elements are interrelated and active [6]. In this context, an effective management of working capital is realized by planning and keeping short-term debt and current assets under control, preventing the risk occurance of nonpayment and avoiding unnecessary investment in current assets [4].

\section{LITERATURE REVIEW}

When literature reviewed, it is usually seen that there are alot of studies claiming that a negative relationship exits between cash conversion time and profitability. As a result of studies it was concluded that impulsive policy in the management of working capital increased the profitability. However, some studies claming opposite of it were determined. Some of these studies can be summarized as follows: [8] have stated in the study performed in 1996 that there was an significant relationship between management of working capital and company's profitability and they determined that the shorter the cash conversion period was ,the better the company's profitability would be. Similarly, [3] revealed at the result of the analysis performed on 58.985 companies between the years of 1975 and 1994 that a negative relationship existed between cash conversion time and company's profitability. Besides that, [9] examined 167 companies traded on ISE and consequently determined that cash conversion time has positive association with liquidity ratios but have negative association with active profitability. On the other hand, [10] found out at the result of the study performed in Belgium that there was a positive relationship between gross operating profitability and size of the company, sales increase and fixed financial assets and also revealed that there was a negative relationship between gross operating profitability and financial liabilities. In light of similar findings [11] examined the relationship between liquidity level and profitability at the manufacturing companies in Saudi Arabia, and used liquidity ratios and cash conversion time as liquidity criteria. As a result of the study,he determined that there was a negative relationship between cash conversion time and active profitability.

Ref. [12] determined as a result of a analysis performed on 111 enterprises operating in Ankara that SMEs used payback period for assessment criteria of investement projects. Besides it was observed that they preferred bank credits rather than equity in terms of choise of financing of investments, and attached quite importance monitoring cash budget and unpaid debts in terms of management of working capital. On the other hand, [13] determined as a result of a analysis performed on 40 enterprises operating in Antalya that SMEs mostly preferred equity when they started to operation and attached quite importance monitoring cash budget and unpaid debts in terms of management of working capital. Similarly, [5] determined as a result of a investigation performed on 30 SMEs operating in Erzurum that, SMEs often used equity and their capacity utilization ratios were low, and they couldn't provide sufficient enployment. Also, [14] studied on 24 SMEs traded at ISE and consequently determined that there were negative relationship between financial leverage ratio of enterprices and liquidity ratio and positive relationship between that and size of the enterprise.In another study, [15] examined the problems caused by crisis concerning SMEs in Uşak province.They determined that nearly $80 \%$ of SMEs didn't have a financing department and had problems in credit collection and usage of bank credit.Also it was determined that nearly $85 \%$ of SMEs suspended investment plans.

Also, [16] come to conclusion through the analysis conducted using quarterly financial tables of ISE quoted companies that there was a negative relationship between profitability and cash conversion time,credit cycle time, and stock cycle time. By examining from a different point of view through the study performed by [17] covering the period of between the years of 1998 and 2005, he come to conclusion that companies wouldn't create any value by applying aggressive investment and financing policy in terms of their business capital. Besides, [18] intended to determine whether or not any relationship existed between management of working capital and company's profitability by using panel data set formed of data of 74 companies operating on ISE covering the period of between the years of 1991 and 2005. As a result of dynamic panel data analysis methods, they determined that a negative relationship existed between profitability and cash conversion time, credit collection time,and stock cycle time and a positive relationship existed between debt payment duration and profitability.

Relating with 75 production companies operating on ISE, [19] come to conclusion that company's profitability would increase as a result of shortening of duration of receivable accounts and cash conversion.They determined that there was a negative relationship between financial leverage ratio 
which is the control variable and company's profitability and also profitability would decrease as financial leverage level increased.Similiarly, it was revealed as a result of analysis performed by [20] comprising 52 enterprises operating in manufacturing sector that company's profitability would increase as cash conversion time decreased. Besides, [21] determined relating to the companies in manufacturing industry operating on ISE that a negative relationship existed between cash cycle and company's performance. Furthermore, [22] revealed relating to accommodation enterprises that working capital and management of was quite important in terms of execution of their activities and increasing profitability.

\section{DATA, VARIABles AND METHODOLOGY}

\section{A. Data}

In order to investigate the relationship between working capital management and firm performance by using different types of variables, the data related to twenty-nine of thirty three companies listed on the BIST SME Industrial Index for last four years obtained official websites of BIST, KAP, and firms. The reason for the four companies excluded in our data set is absence of continuity of the data for the period in the range of these companies.

\section{B. Dependent, Independent and Control Variables}

The dependent (Net Margin, Return on Asset, Retrun on Equitiy), independent (Inventory Turnover, Short-Term Debt Turnover, Cash Conversion Period and WC/Sales Growth) and control (Current Ratio and Leverage Ratio) variables which were taken into account for our research is illustrated in the Table I. It should also be noted that, selected dependent variables are included in the analysis as performance indicators.

\section{Model}

So as to shed light on the possible relationship between working capital management and firm performance in the BIST SME Industrial Index for the period 2010-2014, we employed pooled OLS test and cross sectional time series analysis technique. In this respect, the regression models used for our research are shown below:

$$
\begin{aligned}
& \mathrm{NM}_{\mathrm{it}}=\alpha_{\mathrm{it}}+\beta_{1} \mathrm{IT}+\beta_{2} \mathrm{SD}+\beta_{3} \mathrm{CC}+\beta_{4} \mathrm{WT}+\beta_{5} \mathrm{CR} \beta_{6} \mathrm{LR}_{\mathrm{it}}+\varepsilon_{\mathrm{it}} \\
& i=1 \ldots, N t=1,, T \\
& \mathrm{ROA}_{\mathrm{it}}=\alpha_{\mathrm{it}}+\beta_{1} \mathrm{IT}+\beta_{2} \mathrm{SD}+\beta_{3} \mathrm{CC}+\beta_{4} \mathrm{WT}+\beta_{5} \mathrm{CR} \beta_{6} \mathrm{LR}_{\mathrm{it}}+\varepsilon_{\mathrm{it}} \\
& i=1, \ldots, N t=1,, T
\end{aligned}
$$

$$
\mathrm{ROE}_{\mathrm{it}}=\alpha_{\mathrm{it}}+\beta_{1} \mathrm{IT}+\beta_{2} \mathrm{SD}+\beta_{3} \mathrm{CC}+\beta_{4} \mathrm{WT}+\beta_{5} \mathrm{CR} \beta_{6} \mathrm{LR}_{\mathrm{it}}+\varepsilon_{\mathrm{it}}
$$$$
i=1, \ldots, N t=1, T
$$

Shown in Equations: ROA, ROE and NM performance criteria, and independent variables are IT, SD, CC and WT. In addition, CR and LR represent the control variables. ' $i$ ' refers firms, ' $t$ ' period and ' $N$ ' represents the total number of companies.

\begin{tabular}{lcr}
\multicolumn{4}{c}{ TABLE I: DEPENDENT, INDEPENDENT AND CONTROL VARIABLES } \\
\hline & Dependent Variables (NM, ROA, ROE) & \\
\hline Net Margin & Income After Tax / Tottal Revenue & NM \\
Return on Assests & Net Profit/ Total Assets & ROA \\
Return on Equity & Net Profit/ Equity & ROE \\
\hline \multicolumn{4}{c}{ Independent Variables (ME, ME^2, R(BIST)) } \\
\hline Inventory Turnover (Days) & Total Cost of Revenue / Aver. Inventories & IT \\
Short-Term Debt Turnover (Days) & Short-Term Debt / Total Cost of Revenue & SD \\
& Raveivables Turnover + Inventory Turnover+ & \\
Cash Conversion Period & Short-Term Debt Turnover & CC \\
WC / Sales Growth: & Change in Working Capital to Sales & WT \\
\hline \multicolumn{4}{c}{ Control Variables (Ln(S), K) } & \\
\hline \hline Current Ratio & Current Assets / Current Liabilities & CR \\
Leverage Ratio & Total Debt / Total Assets & LR \\
\hline
\end{tabular}

\section{ANALYSIS}

At the outset of our research, descriptive statistics and correlation coefficients related to dependent, independent and control variables calculated. The potential impact of working capital management on firm performance was tried to figured out by pooled OLS test. Afterwards, considering Hausman test results, the fixed or random effects models were used.

Table II demonstrates the descriptive statistics information of dependent, independent and control variables given at the Table I. According to the Table II, mean, median, standard deviation, number of observation, J. Bera test results and so on of variables can be analyzed at first glance. For instance, the maximum, mean, standard deviation and J. Bera Test values of ROA are 0.42, 0.02, 0.11 and 8584.4 respectively.

Table III shows the matrix for correlation coefficient for variables that are taken into account for analysis. The reason for the calculation of the correlation coefficients of variables is to eliminate the one of variables with a high correlation in order to avoid erroneous results. In other words, if variables are highly correlated, same or opposite movements may lead to erroneous results. In this connection, we removed the one

\begin{tabular}{|c|c|c|c|c|c|c|c|c|c|c|}
\hline & NM & ROA & ROE & RT & IT & SD & WT & $\mathrm{CC}$ & CR & LR \\
\hline Mean & -0.03 & 0.02 & -0.02 & 224.0 & 121.8 & 65.00 & 0.18 & 279.3 & 4.49 & 0.42 \\
\hline Median & 0.01 & 0.01 & 0.01 & 101.2 & 91.05 & 53.30 & 0.01 & 160.5 & 2.03 & 0.20 \\
\hline Max. & 8.91 & 0.42 & 0.84 & 6316.7 & 555.3 & 822.30 & 11.56 & 6456.1 & 64.6 & 3.58 \\
\hline Min. & -9.41 & -0.25 & -3.84 & 20.30 & 5.40 & 4.90 & -17.77 & -600.1 & 0.15 & 0.00 \\
\hline Std. Dev. & 1.29 & 0.11 & 0.39 & 659.4 & 116.2 & 88.53 & 2.56 & 655.2 & 7.85 & 0.64 \\
\hline Skew. & -0.40 & 0.75 & -7.97 & 7.81 & 2.20 & 6.52 & -1.05 & 7.86 & 5.26 & 2.85 \\
\hline Kurtosis & 45.14 & 5.38 & 79.34 & 68.20 & 7.83 & 52.35 & 29.39 & 71.53 & 36.28 & 12.43 \\
\hline J.-Bera & 8584.4 & 38.2 & 29395.7 & 21726.1 & 206.4 & 12595.7 & 3387.4 & 23891.4 & 5886.5 & 586.5 \\
\hline Obser. & 116 & 116 & 116 & 116 & 116 & 116 & 116 & 116 & 116 & 116 \\
\hline
\end{tabular}
of the variables (Receivables Turnover Ratio-RT) from the model due to its high correlation with another variable (Cash Conversion Cycle-CC).

TABLE II: DEPENDENT, INDEPENDENT AND CONTROL VARIABLES 
TABLE III: MATRIX FOR CORRELATION COEFFICIENT

\begin{tabular}{|c|c|c|c|c|c|c|c|c|c|c|}
\hline & NM & ROA & 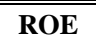 & RT & $\overline{I T}$ & SD & $\overline{\text { WT }}$ & $\overline{\mathrm{CC}}$ & $\overline{C \text { CR }}$ & $\overline{L R R}$ \\
\hline NM & 1 & & & & & & & & & \\
\hline ROA & 0.308 & 1 & & & & & & & & \\
\hline ROE & 0.109 & 0.439 & 1 & & & & & & & \\
\hline RT & -0.268 & -0.048 & 0.005 & 1 & & & & & & \\
\hline IT & -0.131 & -0.292 & -0.068 & 0.058 & 1 & & & & & \\
\hline SD & -0.202 & -0.067 & 0.012 & 0.310 & -0.107 & 1 & & & & \\
\hline WT & -0.127 & -0.039 & -0.028 & 0.495 & 0.070 & 0.579 & 1 & & & \\
\hline $\mathrm{CC}$ & -0.278 & -0.093 & -0.010 & $0.97 *$ & 0.250 & 0.156 & 0.428 & 1 & & \\
\hline CR & 0.095 & 0.302 & 0.116 & 0.067 & -0.018 & -0.130 & 0.055 & 0.081 & 1 & \\
\hline LR & 0.041 & -0.137 & -0.019 & -0.109 & 0.176 & -0.092 & -0.057 & -0.066 & -0.240 & 1 \\
\hline
\end{tabular}

TABLE IV: POOLED REGRESSION RESULTS

\begin{tabular}{|c|c|c|c|c|c|c|c|c|c|}
\hline & \multicolumn{3}{|c|}{$\begin{array}{c}\text { Model -1- } \\
\text { Dependent Variable: } \\
\text { ROA }\end{array}$} & \multicolumn{3}{|c|}{$\begin{array}{c}\text { Model -2- } \\
\text { Dependent Variable: } \\
\text { ROE } \\
\end{array}$} & \multicolumn{3}{|c|}{$\begin{array}{c}\text { Model -3- } \\
\text { Dependent Variable: } \\
\text { NM } \\
\end{array}$} \\
\hline & Coeff. & T-stat & Sig. & Coeff & T-stat & Sig. & Coeff & T-stat & Sig. \\
\hline C & 0.0405 & 1.9285 & $0.056^{*}$ & -0.0510 & -0.6436 & 0.5212 & 0.3545 & 1.4405 & 0.1526 \\
\hline IT & -0.0003 & -3.0173 & $0.003 * * *$ & -0.0002 & -0.6232 & 0.5345 & -0.0011 & -1.0715 & 0.2863 \\
\hline $\mathrm{CC}$ & 0.0000 & -0.4669 & 0.6415 & 0.0000 & 0.1726 & 0.8633 & -0.0005 & -2.6781 & $0.008 * * *$ \\
\hline SD & -0.0001 & -0.6129 & 0.5412 & 0.0003 & 0.5305 & 0.5968 & -0.0033 & -1.9747 & $0.050 * *$ \\
\hline WT & 0.0010 & 0.1887 & 0.8507 & -0.0114 & -0.5745 & 0.5668 & 0.0637 & 1.0359 & 0.3025 \\
\hline CR & 0.0041 & 3.0939 & $0.002 * * *$ & 0.0066 & 1.3129 & 0.1920 & 0.0149 & 0.9575 & 0.3404 \\
\hline LR & -0.0050 & -0.3082 & 0.7585 & 0.0160 & 0.2619 & 0.7939 & 0.0989 & 0.5200 & 0.6041 \\
\hline$\overline{R^{\wedge} 2}$ & & 0.1793 & & & 0.0516 & & & 0.1301 & \\
\hline Adj. $R^{\wedge} 2$ & & 0.1341 & & & 0.0322 & & & 0.0822 & \\
\hline Observ. & & 116 & & & 116 & & & 116 & \\
\hline
\end{tabular}

Note: $* * *, * *$ and $*$ demonstrate statistically significance at level $1 \%, 5 \%$ and $\% 10$ respectively.

According to fundamental assumption that all companies are considered the same in pooled OLS estimation results are demonstrated at Table IV. The regression results which were generated in three panels by taking into account only one dependent variable ROA, ROE and NM in Model 1, Model 2 and Model 3 respectively. At first glance, there is statistically significant negative relationship between Net Margin and, Short Term Debt Turnover and Cash Conversion Cycle. It means that companies face to decline in performance due to any increase in these ratios (number of days). Additionally, we found similar results by using ROA as performance criteria, but these are not statistically significant apart from negative impact of Inventory Turnover days. Although there is a positive relationship between ROE and, Short Term Debt Turnover and Cash Conversion Cycle is observed, they are not statistically significant. It can, also, be claimed that working capital management is crucial to increase company performance, specifically seen by employing ROA and Net Margin ratio as performance measurements.

As basically assumed that all companies in the regression thought to be same is not realistic in market conditions.
Thus, in order to figure out whether fixed or random effects model for our analysis is appropriate, we employed

Hausman Test. According to the Hausman test results, showed in Table V, it is observed that random effect model was more effective than fixed effect model for Model 1, Model 2 and Model 3 at 5\%,10\% and 1\% significance levels respectively.

Table VI demonstrates the random effects model estimation outcomes depending on Hausman Test results at Table V. According to the Table VI, we obtained almost similar results and relationships with outcomes observed by using pooled OLS methodology. To mention in detail, we found negative relationship between ROA and Cash Conversion Cycle at \%10 significance level. In addition, negative relationship between Net Margin and, Short Term Debt Turnover Days and Cash Conversion Cycle at 5\% and $1 \%$ significance level respectively are observed. Moreover, in Model 2, some positive coefficients are found, even though they are still not statistically significant. In a similar vein, as seen in the Model 1 and Model 3, firm performance can be increased by the efficient management of working capital indicators.

TABLE V: STATISTICAL TESTING OF REGRESSION MODELS

\begin{tabular}{lccc}
\hline \hline & Model-1 & Model-2 & Model-3 \\
Hausman Test & 12.970 & 11.971 & 19.221 \\
P-Value & $0.0435^{* *}$ & $0.0626 *$ & $0.0038^{* * *}$ \\
\hline \hline Note: $* * *, * *$ and * demonstrate statistically significance at level 1\%, 5\% and \%10 respectively
\end{tabular}

TABLE VI: RANDOM EFFECTS' ESTIMATION OUTCOMES

$\begin{array}{ccc}\text { Model -1- } & \text { Model -2- } & \text { Model -3- } \\ \text { Dependent Variable: } & \text { Dependent Variable: } & \text { Dependent Variable: }\end{array}$




\begin{tabular}{|c|c|c|c|c|c|c|c|c|c|}
\hline & \multicolumn{3}{|c|}{ ROA } & \multicolumn{3}{|c|}{ ROE } & \multicolumn{3}{|c|}{ Tobin's q } \\
\hline & Coeff. & T-stat & Sig. & Coeff & T-stat & Sig. & Coeff & T-stat & Sig. \\
\hline C & 0.046 & 1.734 & $0.085^{*}$ & -0.050 & -0.638 & 0.525 & 0.341 & 1.393 & 0.167 \\
\hline IT & 0.000 & -1.741 & $0.084 *$ & 0.000 & -0.625 & 0.533 & -0.001 & -0.879 & 0.382 \\
\hline $\mathrm{CC}$ & 0.000 & -0.393 & 0.695 & 0.000 & 0.188 & 0.851 & -0.001 & -2.863 & $0.005 * * *$ \\
\hline SD & 0.000 & -0.623 & 0.535 & 0.000 & 0.532 & 0.596 & -0.003 & -2.025 & $0.045^{* *}$ \\
\hline WT & 0.002 & 0.381 & 0.704 & -0.011 & -0.572 & 0.569 & 0.066 & 1.131 & 0.261 \\
\hline CR & 0.002 & 1.468 & 0.145 & 0.006 & 1.291 & 0.199 & 0.015 & 1.021 & 0.310 \\
\hline LR & -0.013 & -0.806 & 0.422 & 0.016 & 0.271 & 0.787 & 0.077 & 0.417 & 0.678 \\
\hline$R^{\wedge} 2$ & & 0.702 & & & 356 & & & .467 & \\
\hline Adj. $R^{\wedge} 2$ & & 0.561 & & & 051 & & & .213 & \\
\hline Observ. & & 116 & & & 16 & & & 116 & \\
\hline
\end{tabular}

Note: $* * *, * *$ and $*$ demonstrate statistically significance at level $1 \%, 5 \%$ and $\% 10$ respectively.

\section{CONCLUSION}

This research investigate the relationship between working capital management and firm performance of twenty-nine of thirty three companies listed on the BIST SME Industrial Index from 2011 to 2014 (last four years). So as to achieve this purpose, pooled OLS test and cross sectional time series analysis technique and were employed. Additionally, we eliminated one of the selected variables (Receivables Turnover Ratio) due to its high correlation coefficient with Cash Conversion Cycle.

According to pooled OLS test outcomes, we figured out statistically significant negative relationship between Net Margin and, Short Term Debt Turnover and Cash Conversion Cycle. It should be noted that although positive relationships exist for ROE, they were not significant at any levels. The analysis of relationships by using cross sectional time series demonstrates negative relationship between Net Margin and, Short Term Debt Turnover Days and Cash Conversion Cycle at $5 \%$ and $1 \%$ significance level respectively by selecting random effects.

In summary, it can be advocated that there is a relationship between working capital and firm performance as seen in the literature. However, it should be noted that possible data set or period changed may decrease or strengthen the reliability of the outcomes observed from our analyses.

\section{REFERENCES}

[1] A. Arı, KOBİ'ler ve Esnaf Sanatkarlar, Özel İhtisas Komisyonu Raporu, 2013.

[2] M. Altan and G. Şekeroğlu, Çalışma Sermayesinin Finanslama Stratejilerinin Firma Karlılı̆̆ı Üzerine Etkileri: IMKB'de Kayıtlı Firmalar Üzerinde Bir Araştırma, Selçuk Üniversitesi Sosyal Bilimler Enstitüsü Dergisi, pp. 223-228, 2013.

[3] H. Shin and L. Soenen, "Efficiency of working capital and corporate profitability," Journal Financial Practice and Education, vol. 8, pp. 37-45, 1998.

[4] O. Şahin, İMKB'ye Kayıtlı İmalat Şirketlerinde Çalışma Sermayesi Politikaları ve Firma Performansı İlişkisi, Eskişehir Osmangazi Üniversitesi İ̈BF Dergisi, pp. 123-141, 2011.

[5] G. Nazan and Ö. Turan, "Kobi'lerin Finansmanı Erzurum Organize Sanayi Bölgesinde Bir Araştırma,” İktisadi ve İdari Bilimler Dergisi, Cilt 27, Sayı 1, s. pp. 1-17, 2013.
[6] E. Poyraz, İșletme Sermayesi Finanslama Stratejilerinin Karlılık Oranları Üzerindeki Etkisi (Akbank Uygulaması). Dokuz Eylül Üniversitesi İktisadi ve İdari Bilimler Fakültesi Dergisi, pp. 47-56, 2012.

[7] Ö. Akgüç, Finansal Yöntim, İstanbul: Avcıl Basım Yayın, 1998.

[8] M. L. Jose, C. Lancaster, and J. L. Stevens, "Corporate return and cash conversion cycle," Journal of Economics and Finance, vol. 20, no. 1, pp. 33-46, 1996.

[9] T. Yücel and G. Kurt, Nakit Dönüs Süresi, Nakit Yönetimi ve Karlllık: İMKB Şirketleri Üzerinde Ampirik Bir Çalışma. İMKB Dergisi, pp. $1-11,2002$.

[10] M. Deloof, "Does working capital management affect profitability of Belgian firms?" Journal of Business Finance \& Accounting, vol. 30, no. $3 \& 4$, pp. $573-587,2003$.

[11] A. Eljelly, "Liquidity-profitability trade-off: An empirical investigation in an emerging market," International Journal of Commerce \& Management, vol. 14, no. 2, pp. 48-61, 2004.

[12] Ö. Arslan, Küçük ve Orta Ölçekli İşletmelerde Çalışma Sermayesi ve Bazı Finansal Yönetim Uygulamaları. C.Ü. İktisadi ve İdari Bilimler Dergisi, pp. 121-135, 2003.

[13] A. C. Cetin, Y. Akyüz, and E. Genç, Küresel Kriz Sürecinde İmalat Sanayi İşletmelerinin Finansal Sorunlarının Değerlendirilmesi (Uşak İli Örneği). Süleyman Demirel Üniversitesi Sosyal Bilimler Enstitüsü Dergisi, pp. 101-118, 2011.

[14] S. Güler, İstanbul Menkul Kıymetler Borsasına (IMKB) Kayıtlı Küçük ve Orta Büyüklükteki İşletmelerin (KOBİ) Sermaye Yapıları Üzerine Bir Uygulama. Süleyman Demirel Üniversitesi İktisadi ve İdari Bilimler Fakültesi Dergisi, pp. 353-371, 2010.

[15] A. Çetin and A. İ. Bitırak, Antalya İli Küçük ve Orta Ölçekli İşletmelerinde Finansal Yönetim, İşletme Sermayesi ve Yatırım Bütçelemesi Uygulamaları. Alanya İşletme Fakültesi Dergisi, pp. 119-137, 2009.

[16] F. Şamiloğlu and K. Demirgüneş, "The effect of working capital management on firm profitability: Evidence from Turkey," The International Journal of Applied Economics and Finance, vol. 2, pp. 44-50, 2008

[17] M. S. Nazir and T. Afza, "Working capital requirements and the determining factors in Pakistan," The Lefai Journal Applied Finance, pp. 28-38, 2009.

[18] E. Coşkun and D. Kök, Çalışma Sermayesi Politikalarının Karlılık Üzerine Etkisi: Dinamik Panel Uygulaması, Ege Akademik Bakış, pp. 75-85, 2011.

[19] G. Vural, A. G. Sökmen, and E. H. Çetenak, "Affects of 'Working capital management on firm's performance: Evidence from Turkey', International Journal of Economics and Financial Issues, pp. 488495, 2012.

[20] H. M. Çakır, "Nakit Döngüsünün Firma Karlılığına Etkışının Sektörel Analizi," Journal of Yaşar University, pp. 4948-4965, 2013.

[21] R. Akbulut, İMKB'de İmalat Sektöründeki İşletmelerde İşletme Sermayesi YönetimininKarlılık Üzerindeki Etkisini Ölçmeye Yönelik Bir Araștırma," İstanbul Üniversitesi İşletme Fakültesi Dergisi, vol. 40, no. 2, 2011. 
[22] S. B. Erdinç, Konaklama İşletmelerinde İşletme Sermayesi Yönetiminin İncelenmesi, Afyon Kocatepe Üniversitesi İIBF Dergisi, pp. 223-236, 2008.

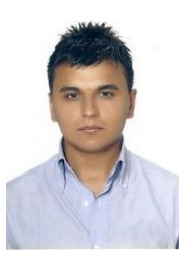

Fatih Konak was born in Ankara, Turkey in 1984. He finished undergraduate level in Turkey at Anadolu University FEAS Public Finance. Then, he obtained MSc in finance from University of Bradford, UK. He is still doing $\mathrm{PhD}$ in finance at Erciyes University, Turkey. İn addition, he is working as a teaching assistant at Hitit University in Çorum, Turkey. His research interests are efficient market hypothesis, financial institutions, derivatives, and international stock markets.

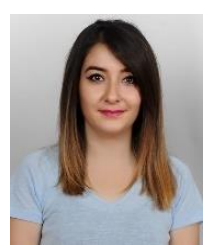

Ela Nur Güner was born in Amasya/Turkey in 1991. She finished undergraduate level in Turkey at Hiti University, FEAS, Business Administrations. She is still doing MSc in Accounting at Hitit University, Turkey. 